\title{
RENAL COMPLICATIONS IN HIV PATIENTS IN AND AROUND MADURAI- A CROSS-SECTIONAL STUDY
}

\author{
Balasubramanian Narayana Srinivasan ${ }^{1}$, A. J. S. Pravin ${ }^{2}$
}

${ }^{1}$ Assistant Professor, Department of Dermato-Venereology, Kanyakumari Government Medical College, Asaripallam, Nagercoil. 2 Professor and HOD, Department of Dermato-Venereology, Kanyakumari Government Medical College, Asaripallam, Nagercoil.

ABSTRACT
BACKGROUND
HIV is the modern pandemic spreading throughout the world in a rampant manner. The renal manifestations of HIV infection
occurs commonly during all stages of infection [Medical management of AIDS- Merle A Sande et al, Renal Manifestations of HIV
infection occurs in 6\% - 10\% of HIV seropositive individuals] [Kidney Int 44:1327-1340, 1993; AmJ Kidney Dis 26: 446-453, 1995].
Fluid, electrolytes and acid-base abnormalities as well as acute renal failure have been observed frequently, mainly as a
consequence of drug toxicity or opportunistic infections [Medical Management of AIDS- Merle A. Sande].

The objectives of this study are-

1. To find out prevalence of renal failure among HIV patients admitted to tertiary care hospital.

2. To find out the spectrum of renal manifestations in HIV positive patients hospitalised at STD ward.

\section{MATERIALS AND METHODS}

It is a cross-sectional study. The study was conducted in HIV positive patients who were admitted in STD ward, Government Rajaji Hospital, Madurai during the period from 01-02-2002 to 31-01-2004 (2 years). The total number of inpatients are 360, of which 30 are fit to be included in the study. The criteria for including in the study are significant proteinuria, elevated serum creatinine of more than $1.5 \mathrm{mg} / \mathrm{dL}$ or presence of both.

\section{RESULTS}

360 HIV patients were admitted during the study period and 30 were found fit for the study, i.e. out of 360 HIV patients, $8.33 \%$ suffered from renal involvement. In our study, 30 - 39 age group constituted $50 \%$ and males are affected more than females.

\section{CONCLUSION}

HIV is a common problem in our clinical practice. Renal involvement in HIV patients carries poor prognosis. The most common age group affected are 20 - 45 years. Males seek the medical help more often than females and this could be the reason for male predominance in our study. So it is important to detect all cases early and treat effectively to improve the quality of life.

\section{KEYWORDS}

AIDS, HIVAN, Focal Segmental Glomerulosclerosis, End Stage Renal Disease.

HOW TO CITE THIS ARTICLE: Srinivasan BN, Pravin AJS. Renal complications in HIV patients in and around Madurai- a crosssectional study. J. Evolution Med. Dent. Sci. 2017;6(74):5296-5302, DOI: 10.14260/Jemds/2017/1150

\begin{tabular}{ll}
\hline BACKGROUND & $\begin{array}{c}\text { The progression of HIV disease is more rapid in patients } \\
\text { whe renal manifestations of HIV infection occur commonly }\end{array}$ \\
$\begin{array}{l}\text { during all stages of infection. Fluid, electrolytes and acid-base } \\
\text { abnormalities as well as acute renal failure have been }\end{array}$ & $\begin{array}{l}\text { stagenal disease who become infected with HIV as a result } \\
\text { of haemodialysis or renal transplantations. }\end{array}$
\end{tabular}
observed frequently, mainly as a consequence of drug toxicity or opportunistic infections or due to direct consequence of HIV infection. Renal manifestations of HIV infection occurs in $6 \%-10 \%$ of HIV seroreactive individuals. $(1)$ The susceptibility of blacks, men and persons with H/O IDU suggests both genetic and environmental factors may modulate the development of HIV-associated renal disease. The most clinically relevant disorder is chronic renal failure progressing to end-stage renal disorder (ESRD), which has also been observed with a high frequency in some centres and caused by HIVAN (HIV associated immune mediated renal disease) (20-22 Merle Sande).(2)

Financial or Other, Competing Interest: None.

Submission 09-08-2017, Peer Review 02-09-2017,

Acceptance 08-09-2017, Published 14-09-2017.

Corresponding Author:

Balasubramanian Narayana Srinivasan,

Plot No. 25, D. No. 10, Kasim Nagar, $2^{\text {nd }}$ Street,

Kamatchi Nagar, $2^{\text {nd }}$ Main Road,

V. M. Chatram, Tirunelveli-627011.

E-mail:drsriniart@gmail.com

DOI: $10.14260 /$ jemds $/ 2017 / 1150$

\section{MATERIALS AND METHODS}

\section{Study Design}

The cross-sectional study was conducted in the STD ward, Government Rajaji Hospital, Madurai, during the period from 01-02-2002 to 31-01-2004 (2 years). All the symptomatic HIV patients admitted in the STD ward during the above period were taken and those fit with the eligibility criteria were included in the study.

\section{Objectives}

1. To find out prevalence of renal failure among HIV patients admitted to tertiary care hospital.

2. To find out the spectrum of renal manifestations in HIV positive patients.

\section{Sample Size}

The total numbers of in-patients were 360 , of which 30 were fit to be included in the study.

\section{Inclusion Criteria}

1. Significant proteinuria. 
2. Elevated serum creatinine of more than $1.5 \mathrm{mg} / \mathrm{dL}$ or presence of both.

\section{MATERIALS AND METHODS}

All symptomatic patients were admitted in the ward and selected for the study once they fulfilled the criteria. Proteinuria can be categorised into three groups depending on 24 hours urinary protein estimation. Proteinuria upto 300 $\mathrm{mg} /$ day is normal. Mild proteinuria- $300 \mathrm{mg}$ to $1.5 \mathrm{gm} /$ day; Moderate proteinuria- $1.5 \mathrm{gm}$ to $3.5 \mathrm{gm} /$ day; Severe proteinuria- more than $3.5 \mathrm{gm} /$ day.

Likewise, renal failure also can be categorised on the basis of serum creatinine level. Mild RF- 1.5 to $3 \mathrm{gm} / \mathrm{dL}$; Moderate RF- 3 to $5 \mathrm{gm} / \mathrm{dL}$; Severe RF- more than $5 \mathrm{gm} / \mathrm{dL}$.

Creatinine Clearance estimated in these Patients using Cockcroft Formula

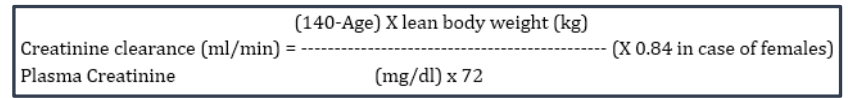

Creatinine clearance categorised into three groups- $>50$ $\mathrm{mL} / \mathrm{min}=$ mild renal insufficiency; $30-50 \mathrm{~mL} / \mathrm{min}=$ moderate renal insufficiency; $<30 \mathrm{~mL} / \mathrm{min}=$ severe renal insufficiency.

A urinary protein-creatinine concentration ratio on the first voided morning urine sample is a useful substitute for repeated 24 hours urine protein estimation; normal below 2; values $>3$ suggest the presence of nephrotic range proteinuria. Microalbuminuria indicates excretion of albumin of $20-200 \mu \mathrm{gm}$ per minute (albumin excretion rate of) of a daily excretion of albumin in the range of $30-300 \mathrm{mg}$.

In all selected patients, thorough history taking and physical examination were done with special references to renal system.

The following Investigations were done

\begin{tabular}{|c|c|}
\hline $\begin{array}{c}\text { Complete } \\
\text { Haemogram }\end{array}$ & Motion routine \\
\hline Urine Routine & Renal parameters \\
\hline Urine C/S & Blood Glucose \\
\hline $\begin{array}{c}24 \text { hrs. Urinary } \\
\text { Protein }\end{array}$ & $\begin{array}{c}\text { Serum electrolytes, calcium, phosphorus, } \\
\text { cholesterol, alk. P04, proteins }\end{array}$ \\
\hline $\begin{array}{c}\text { Creatinine } \\
\text { Clearance }\end{array}$ & CXR PA and USG Abdomen \\
\hline
\end{tabular}

\section{Statistical Analysis}

This study is a cross-sectional study. Statistical analysis of the data was performed using the Statistical Package for the Social Sciences (SPSS), version 15. The test of significance is done with Chi-square test. ' $P$ ' value $<0.05$ was considered as significant.

\section{RESULTS}

Total number of inpatients - 360; Males - 348; Females - 12; 30 were selected and included in the study and further evaluated. Out of 360 , renal involvement was seen in $8.33 \%$ patients; 30 - 39 age group constitutes about 50\% and males are affected predominantly. All were presented with proteinuria and anaemia. Half of the population presented with generalised symptoms like fever, loss of appetite, loss of weight, etc. Specific presentations like pedal oedema and facial puffiness were noted in $16 \%$ of patients only. Characteristically, none of them presented with hypertension.

\section{Other System Involvement}

\begin{tabular}{|c|c|}
\hline Meningitis- 3.33\% & Psoriasis- 3.33\% \\
\hline HIV retinopathy- 10\% & $\begin{array}{c}\text { Multidermatomal } \\
\text { Herpes Zoster- } 6.66 \%\end{array}$ \\
\hline CMV retinitis- 3.33\% & Oral candidiasis- 56.66\% \\
\hline $\begin{array}{c}\text { Pulmonary } \\
\text { tuberculosis- 76.66\% }\end{array}$ & Oral herpes- 3.33\% \\
\hline HIV prurigo- $6.66 \%$ & Genital herpes- 3.33\% \\
\hline
\end{tabular}

\section{Outcome}

2 patients died at hospital due to comorbid conditions. Others followed up as OPD.

\section{Management}

None underwent dialysis. Renal biopsy was not done due to poor general condition.

Serological and Sonographic Presentation and Corelation

Out of 30 patients, 16 had renal failure clinically. Males were affected more with RF. Mild RF- 9 patients (30\%); Moderate RF- 3 patients (10\%); Severe RF- 4 patients (13.33\%) 13 have sonographic evidence of renomegaly ( $>11.5 \mathrm{~cm}$ in length) with echogenicity. The percentage of renomegaly was $43.33 \%$; 8 out of 16 RF patients had renomegaly. Characteristically, renomegaly was seen in all patients with severe RF and in 5 patients with normal serum creatinine level.

\begin{tabular}{|c|c|c|c|c|}
\hline & \multirow{3}{*}{$\begin{array}{c} \\
0 \text { (Normal Sr. } \\
\text { Creatinine) }\end{array}$} & \multicolumn{2}{|c|}{ Renomegaly } & \\
\hline & & Prese & bsent & \\
\hline \multirow{5}{*}{$\begin{array}{l}\text { Renal Failure Grade } \\
\text { (Total } 16 \text { Patients) }\end{array}$} & & 5 & 9 & 14 \\
\hline & I & 4 & 0 & 4 \\
\hline & II & 2 & 1 & 3 \\
\hline & III & 2 & 7 & 9 \\
\hline & Total & 13 & 17 & 30 \\
\hline \multicolumn{5}{|c|}{ Renal Failure vs Renomegaly } \\
\hline
\end{tabular}

$\mathrm{DF}=3$; (Chi square) X2 = 7.8604; $\mathrm{P}=0.04899$ (Significant Strong association RF vs renomegaly)

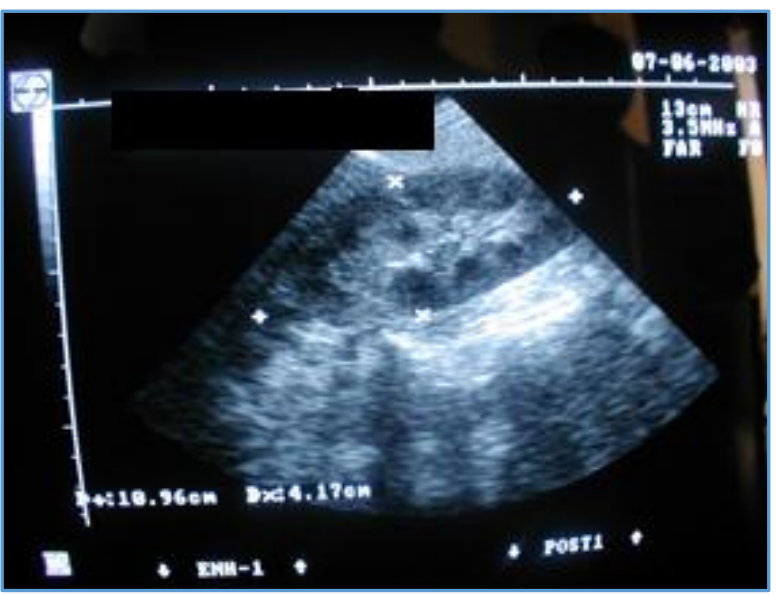




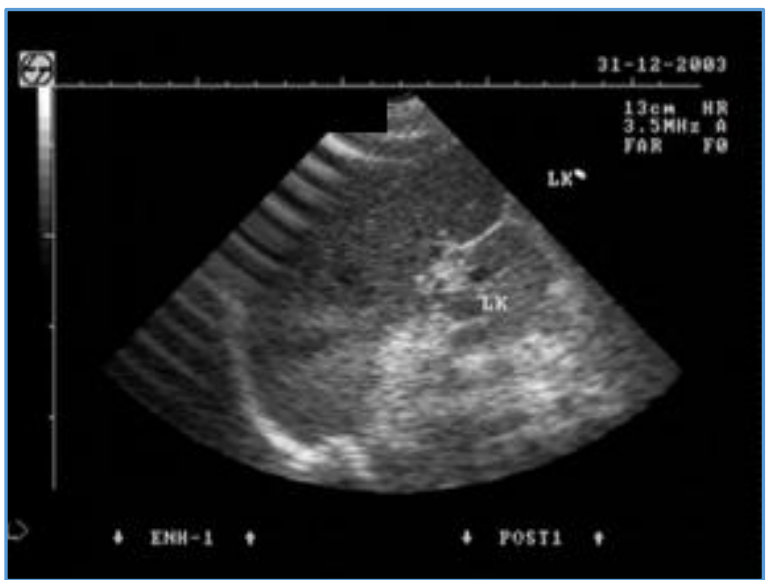

Fig. 1. Normal Kidney; Fig. 2. Lt. Renomegaly
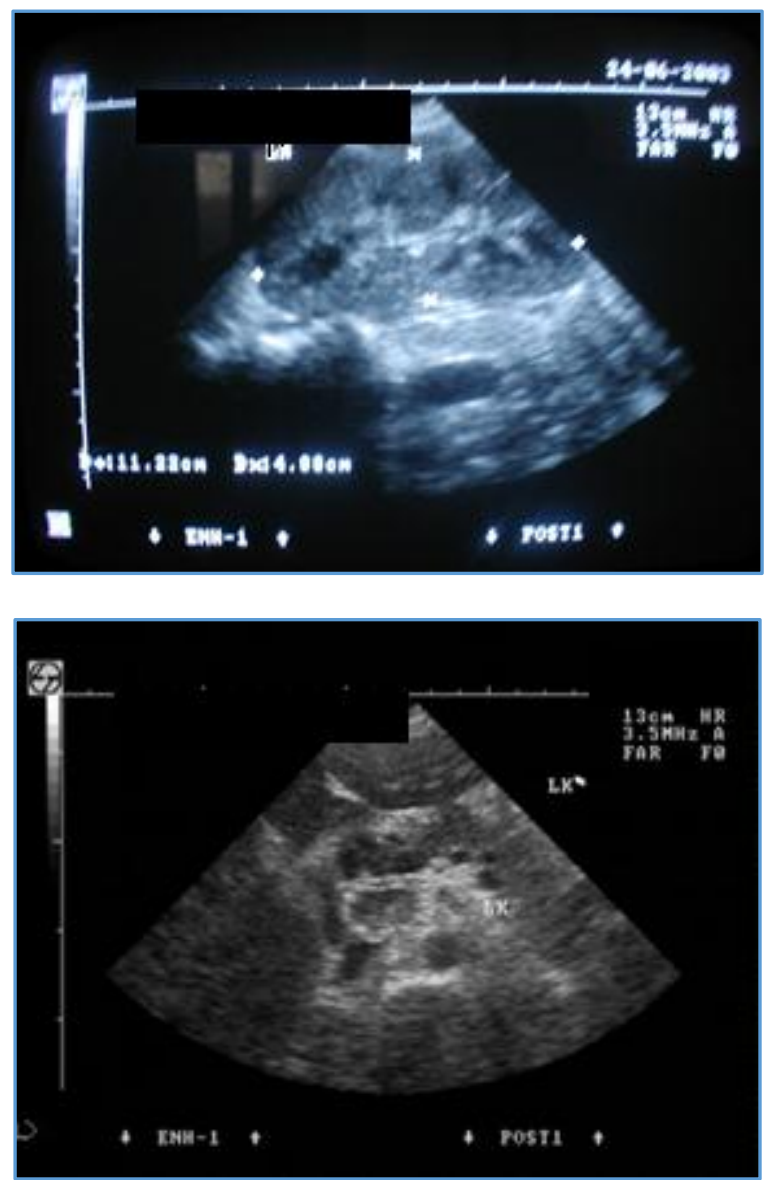

Fig. 3. Renomegaly with Hydronephrosis; Fig. 4. Hydronephrosis

Creatinine clearance as per Cockcroft formula. Characteristically, all the patients had reduced Cr. clearance.

\begin{tabular}{|l|c|c|c|c|c|}
\hline \multicolumn{3}{|c|}{} & \multicolumn{5}{|c|}{ Renal Failure } \\
\hline \multirow{3}{*}{$\begin{array}{c}\text { Creatinine } \\
\text { Clearance }\end{array}$} & & $\begin{array}{c}\text { Mild } \\
\text { (III) }\end{array}$ & $\begin{array}{c}\text { Moderate } \\
\text { (II) }\end{array}$ & $\begin{array}{c}\text { Severe } \\
\text { (I) }\end{array}$ & $\begin{array}{c}\text { Sr. } \\
\text { Creatinine }\end{array}$ \\
\cline { 2 - 7 } & I & 1 & 7 & 0 & 12 \\
\cline { 2 - 6 } & II & 7 & 0 & 1 & 2 \\
\cline { 2 - 6 } & III & 1 & 3 & 3 & 0 \\
\hline \multicolumn{6}{|c|}{ Creatinine Clearance vs RF } \\
\hline
\end{tabular}

$\mathrm{Df}=4 ; \mathrm{X} 2=9.42 ; \mathrm{P}=0.0448$ (Significant)

\begin{tabular}{|c|c|c|c|}
\hline \multirow{2}{*}{$\begin{array}{c}\text { Creatinine } \\
\text { Clearance }\end{array}$} & & \multicolumn{2}{|c|}{ Renomegaly } \\
\cline { 2 - 4 } & I & Present & Absent \\
\cline { 2 - 4 } & II & 2 & 9 \\
\cline { 2 - 4 } & III & 7 & 8 \\
\hline \multicolumn{2}{|c|}{ Total } & $\mathbf{1 3}$ & $\mathbf{1 7}$ \\
\hline \multicolumn{2}{|c|}{ Creatinine Clearance vs Renomegaly } \\
\hline
\end{tabular}

$\mathrm{Df}=2 ; \mathrm{X} 2=12.207 ; \mathrm{P}=0.0022$ (Significant)

\begin{tabular}{|c|c|c|c|}
\hline Normal Study & 7 & Pancreatic involvement & 3 \\
\hline Cystitis & 1 & Medical Renal Disease & 12 \\
\hline Renal Calculi & 2 & Other findings & 8 \\
\hline Hydronephrosis & 4 & & \\
\hline \multicolumn{4}{|c|}{ Sonographic Presentation } \\
\hline
\end{tabular}

In our study, 5 out of 30 patients had serological syphilis.

\section{A. Proteinuria}

All 30 patients presented with significant proteinuria. Prevalence of significant proteinuria was 8.33\%; Mild Proteinuria - 24 patients (80\%); Moderate Proteinuria - 4 patients (13.4\%); Severe Proteinuria - 2 patients $(6.6 \%)$. The mean $24 \mathrm{hrs}$. urinary protein in patients with renal failure was $1.06 \mathrm{gm}$, which is more than in the patients without renal failure. ' $\mathrm{P}$ ' is 0.021 (significant as ' $\mathrm{P}$ ' $<0.05$ ).

\section{B. Creatinine Clearance}

15 out of 30 cases with significant proteinuria and renal failure had creatinine clearance of less than $50 \mathrm{~mL} / \mathrm{min}$; the mean creatinine clearance in RF patients was $27.65 \mathrm{~mL} / \mathrm{min}$, which is much lower than the patient without RF (56.71 $\mathrm{mL} / \mathrm{min}$ ). ' $\mathrm{P}$ ' $=0.00008$ (significant). However, all the individuals in the study group with significant proteinuria had reduced creatinine clearance.

\section{Blood Urea}

The mean blood urea in RF patients was $88.27 \mathrm{mg} / \mathrm{dL}$ which is greater than normal value. ' $\mathrm{P}$ ' is $0.001=$ significant.

\section{Serum Creatinine}

The mean serum creatinine level in RF patients was above 3.5 $\mathrm{mg} / \mathrm{dL}$, which is significant as $\mathrm{p}=0.001$; Co-relation of proteinuria, elevated sr. creatinine (RF) and renomegaly:

\begin{tabular}{|c|c|}
\hline Proteinuria with renomegaly without RF & 5 \\
\hline Proteinuria with renomegaly with RF & 8 \\
\hline Proteinuria with RF without renomegaly & 8 \\
\hline Only proteinuria (neither RF nor renomegaly & 9 \\
\hline
\end{tabular}

\begin{tabular}{|c|c|c|c|c|c|c|}
\hline \multirow[b]{2}{*}{$\begin{array}{c}\text { Parameters } \\
\text { (Serum) }\end{array}$} & \multicolumn{5}{|c|}{ Number of Patients } & \multirow[b]{2}{*}{$\begin{array}{c}\text { Significance } \\
\text { with } \\
\text { Respect to } \\
\text { RF }\end{array}$} \\
\hline & 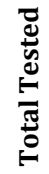 & 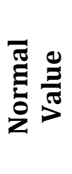 & 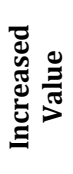 & 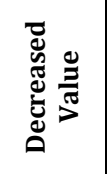 & فू & \\
\hline Calcium & 25 & 1 & 0 & 24 & 0.112 & Not Significant \\
\hline Phosphorous & 25 & 13 & 9 & 3 & 0.73 & Not Significant \\
\hline Cholesterol & 30 & 28 & 2 & 0 & 0.22 & Insignificant \\
\hline Alk.PO4 & 30 & 9 & 21 & 0 & 0.88 & Insignificant \\
\hline Sodium & 30 & 14 & & $\begin{array}{c}16 \\
(15 \mathrm{RF}) \\
\end{array}$ & 0.0001 & Significant \\
\hline Potassium & 30 & 15 & 15 & 0 & 0.0004 & Significant \\
\hline Bicarbonates & 30 & 22 & 3 & 5 & 0.0001 & Significant \\
\hline Chloride & 30 & 28 & 2 & 0 & 0.86 & Insignificant \\
\hline $\begin{array}{c}\text { Proteins } \\
\text { (Total) }\end{array}$ & 30 & 15 & 4 & 11 & 0.68 & Insignificant \\
\hline Albumin & 30 & 9 & 0 & 21 & 0.59 & Insignificant \\
\hline
\end{tabular}


I. Review of Literature/Classification

Acute Renal Failure and Fluid and Electrolyte Disorders

(i) Causes of Acute renal failure: Pre-renal, Renal and Postrenal.

\section{Prerenal}

Volume depletion (Diarrhoea, Bleeding, Decreased intake and NSAIDs), Sepsis, Early obstructive uropathy.

\section{Renal}

1. Acute tubular Necrosis: Ischaemia/ hypoperfusion; Sepsis/ endotoxaemia; Radiocontrast exposure, Nephrotoxic antibiotics- Amphotericin B, Aminoglycosides, Pentamidine, Foscarnet, Acyclovir, Cidofovir, Tenofovir.

2. Acute interstitial nephritis- Sulfamethoxazole, Dapsone, NSAIDs and Rifampin.

3. Glomerular disease- HIVAN; HCV- MPGN (Mesangioproliferative GN); other primary GNpathies.

4. Infiltrative lesions- Kaposi's sarcoma, Renal cell carcinoma, Lymphoma and Amyloidosis.

5. Vasculitis- Haemolytic- Uraemic syndrome; Thromboticthrombocytopenic purpura; renal cortical infarction.

6. Systemic infections- Mycobacterium species, Candida species, Cryptococcus sp, Aspergillosis, Cytomegalovirus, Bacterial endocarditis, Renal microabscess formation.

7. Miscellaneous- HAN (Heroin-associated nephropathy), Nephrosarca (Renal oedema with severe hypoalbuminaemia), Chemical interference with the creatinine assay; Trimethoprim-sulfamethoxazole, Cephalosporins and Cimetidine.

\section{Post Renal Obstruction}

1. Drugs causing crystalluria-Sulfadiazine, Indinavir, Acyclovir.

2. Malignancy.

\section{Mild ARF}

Defined as a peak serum creatinine $>=2.0 \mathrm{mg} / \mathrm{dL}$. Occurs in upto $20 \%$ of hospitalised HIV infected patients.(3) Patients with ARF on admission to the hospital are likely to have a pre-renal cause related to hypovolaemia. In patients who develop during the hospitalisation, the likely cause is acute tubular necrosis.(4) Both foscarnet and tenofovir are associated with development of nephrogenic diabetes insipidus.

\section{Severe Renal Failure}

In HIV infected patients, sepsis contributes to the development of severe renal failure, defined as a peak creatinine $>=6.0 \mathrm{mg} / \mathrm{dL}$ associated with terminal conditions, in which acute dialysis would be inappropriate. When the acute underlying illness is reversible; however, ARF will usually reverse with dialysis and conventional supportive care. Acute interstitial nephritis has been found in $13 \%$ of autopsies done in patients with renal dysfunction and an inciting agent is usually not identified (HIV Insite 2003). Obstructive uropathy may be the result of abdominal adenopathy or sludge formation in the collecting system due to crystallisation of protease inhibitors and Acyclovir. Rare opportunistic infections such as isolated renal mucormycosis have also been described. Renal function generally is restored once rigorous hydration is administered and the inciting agent is discontinued.

\section{(ii) Disorders of Osmolality}

\section{Hyponatraemia}

Most common, reported in $30 \%-60 \%$ of hospitalised; is a poor prognosis.(5) SIADH is the likely culprit during hospitalisation.(3) SIADH is usually associated with common pulmonary and intracranial diseases such as pneumocystis pneumonia, toxoplasmosis and tuberculosis. (6)

Adrenal pathology, particularly CMV infection is found common in patients who have died from AIDS.(7) Other pathologic lesions that have been noted frequently include haemorrhage; infiltration with Kaposi's sarcoma and lymphoma.

\section{(iii) Potassium Disorders}

Both hypo- and hyperkalaemia are common in HIV infected patients.

\section{(iv) Acid Base Disorders}

Commonly due to infections or drugs. (8) Respiratory alkalosis and respiratory acidosis may occur in opportunistic infections of the lungs or CNS. Both high and non-anion gap metabolic acidosis are also seen.(9)

\section{GLOMERULAR RENAL DISEASE}

(A) HIV associated Nephropathy (HIVAN)

\section{a. Epidemiology}

HIVAN is a unique clinical and histopathological entity- focal segmental glomerulosclerosis (FSGS) and it is thought to develop as a result of HIV gene expression in renal tissue. HIVAN may be the initial manifestation of HIV infection. HIVAN represents a major complication of HIV infection.(10) HIVAN has become the most common single diagnosis in HIV infected patients with renal insufficiency.

\section{b. Pathogenesis}

HIVAN is caused by HIV gene expression in renal tissue, resulting in injury of glomerular and tubular epithelial cells. This accounts for leakage of filtered proteins (nephrotic syndrome) and renal failure. HIV is a potent stimulator of transforming growth factor $-\beta$, a cytokine strongly implicated in the development of fibrosis.(11)

There are evidences to indicate a strong association between HIV and HIVAN. HIV, DNA and protein markers specific for HIV have been demonstrated in tubular epithelium, glomerular epithelial cells and mesangial cells by a variety of techniques in vitro and in renal biopsy tissue of HIV patients. ${ }^{(12)}$

Kidney may serve as a viral reservoir harbouring HIV strains that have evolved under tissue-specific selection pressures.(13)

\section{(c) Clinical Manifestation}

HIVAN is recognised throughout the spectrum of HIV disease. It can be the first manifestation of HIV infection or even precede detection of HIV antibodies.(14) Renal manifestations of HIV infection occurs in $6 \%-10 \%$ of HIV seropositive individuals. Proteinuria is the hallmark of this disorder.(15) Clinical presentation typically includes- 
- $\quad$ High grade proteinuria, usually in nephrotic range $(>3.5$ gms/day), but no haematuria.

- Normal or large kidneys with increased echogenicity on diagnostic ultrasound.

- Noteworthy is the rarity of hypertension and peripheral oedema in these patients despite the severity of renal failures and proteinuria.(16) Prognosis may depend on the clinical status of HIV infection, the presence of ESRD or both.

- Hypoalbuminuria disproportionate to the degree of proteinuria and rapidly progressive renal insufficiency.

- HIVAN has poor prognosis, most patients progress quickly to ESRD within 2 to 6 months.

\section{(d) Histopathology}

HIVAN is associated with characteristic glomerular tubulointerstitial and ultrastructural lesions. Autopsy data demonstrate that $90 \%$ of patients with the clinical diagnosis of HIVAN have focal and segmental glomerulosclerosis (FSGS).(5)

\section{Renal Ultrasound}

In patients with HIVAN typically shows normal or enlarged renal silhouette $(>12.3 \mathrm{~cm})$ with increased echogenicity, even with advanced renal failure. Renomegaly may be the result of insufficient time for global sclerosis and fibrosis given the rapid progression of renal disease. Marked dilatation of the tubules with numerous microcysts, in contrast to the tubular collapse is frequently seen in other forms of chronic renal injury and interstitial oedema.(17)

\section{(e) Clinical Course and Treatment}

Until recently, the clinical course of HIVAN was one of inexorable progression to ESRD in 6 - 12 months with limited treatment options. Options now available are anti-retroviral therapy (ART), steroid treatment and ACE inhibitors (ACEI's). Renal biopsy should be offered to patients as the treatment implications and prognosis vary according to the biopsy results.

\section{Risk Factors for Progressive Renal Disease Include}

- $\quad \mathrm{CD}_{4}$ count $<200$ cells $/ \mu \mathrm{L}$

- Detectable HIV RNA level.

- Hypertension.

- Low albuminaemia.

- $\quad$ Elevated serum creatinine.(18)

Combination ART should be initiated early in these patients, because serum viral loads do not necessarily reflect the severity or rate of progression of HIVAN.(19) The degree of renal insufficiency should influence the choice and dose of individual antiretroviral agents. The AIDS Clinical Trials Group (ACTG) is currently developing a clinical trial (Photocol A5179) to compare treatment with an angiotensin receptor blocker (Valsartan) plus ART to ART alone in patients with HIVAN.

The role of corticosteroid treatment remains controversial, but may be considered in patients with HIVAN and early HIV disease whose renal failure is progressing rapidly. There is $20 \%$ to $40 \%$ response rate of corticosteroids. Prednisolone $60 \mathrm{mg} /$ day for 2 to 11 weeks leads to a significant reduction in serum creatinine and 24- hours urine protein excretion(20) (due to reversal of interstitial inflammation) and $80 \%$ reduction in risk of progressive azotaemia.(21)

Angiotensin II increases the cellular synthesis of transforming growth factor -beta (TGF-Beta), which has been implicated in the pathogenesis of HIVAN; ACE-inhibitors (Captopril and Fosinopril) are effective in slowing the progression of renal insufficiency by reducing production of TGF-Beta in both humans and HIV-transgenic mice. Studies suggest that ACE-I's initiated early may offer renal survival benefits in HIVAN (22). ACE-I's should certainly be the antihypertensive drug of choice in HIV infected patients with renal disease and hypertension, and should be considered in normotensive HIV infected patients with renal disease.

\section{(C) End-Stage Renal Disease (ESRD)}

HIVAN has become the third leading cause of ESRD among African Americans aged 20 - 64 yrs.(23) Management options for these patients include- 1) Haemodialysis; 2) Peritoneal dialysis; 3) Transplantation.

\section{(v) Medical Management}

The standard Dialysis Outcome Quality Initiative (DOQI) recommendations should be followed for HIV-infected patients with ESRD.(24)

- HIV patients with ESRD respond well to erythropoietin therapy.

- $\quad$ HCV co-infection is very common in HIV infected ESRD patient. Optimal therapy for HCV infection in the ESRD patient is not known. HIV/HCV co-infected patients should be discouraged from alcohol use and should be vaccinated for Hepatitis A and B virus.

- The nucleoside and nucleotide analogue reverse transcriptase inhibitors require dose adjustment in patients with renal insufficiency.

\section{DISCUSSION}

HIV infection is a common problem in our clinical practice. Renal involvement in HIV carries poor prognosis; 30 patients were studied that included 24 males and 6 females. In our study group, 12 were from urban areas and 18 were from rural areas of Madurai; 14 out of 30 patients were illiterates. Males predominate and constitutes $80 \% ; 76 \%$ are in the age group of 20 - 30 years. Schoenfeld P et al, says that HIVAN is more common in men than females and most common age group affected are between 20 - 45 years. (25) This observation correlates with our study. Most of our patients belong to agri cooly group. Most of them go outside on work purposes and other business activities. Moreover, males are one who comes for consulting for their sexual related problems, which would be the reason for the male predominance.

In our study, $8.33 \%$ of HIV positive in-patients were suffering from renal involvement. Shusterman et al, also states that renal manifestations of HIV infection occurs in $6 \%$ - $10 \%$ of HIV seropositive individuals.(17) This study correlates with our observation.

In our study, $76.66 \%$ of patients suffered from pulmonary tuberculosis at the time of renal involvement and they were on ATT or completed ATT. Anthony S Fauci in Harrison's text book of Medicine, in the chapter of HIV: AIDS and related disorders has reported that in developing countries approximately $60 \%$ to $80 \%$ of patients have pulmonary TB 
and $30 \%$ to $40 \%$ have extrapulmonary TB. William Powderly, MD, Professor of Medicine, Washington University, School of Medicine, St. Louis studied on HIV patients who had migrated to UK from tuberculosis endemic areas and found extremely high rates of TB. HIV infection is an infrequent cause of chronic renal failure (CRF) among patients at the Hammersmith Hospital, London and the data (study period 1994 to 1999) suggests that RF requiring renal replacement therapy is as potent as a risk factor for reactivation of TB as any (HIV, etc.). These findings correlates with our study because of higher prevalence of TB in our country.

In our study, $8.3 \%$ of patients had significant proteinuria $>1 \mathrm{gm} /$ day noted in 6 patients. Nephritic proteinuria was noted in (2 cases) $6.6 \%$ of study patients.

Parvo et al reported in an outpatient study of $32 / 75$ (43\%) AIDS patients and in another study on inpatients of $85 / 182$ (47\%) were found to have proteinuria. Bourgoignie JJ reported that studies from black heterosexuals and drug addicts with AIDS revealed nephrotic range proteinuria in upto $6 \%-10 \%$ of patients. PP Varma et al, described a variety of renal lesions have been reported in HIV patients from western world(15); 25 (17.6\%) of the 142 patients screened had proteinuria. Bourgoignie et al, reported that most patients diagnosed to have HIVAN excreted $1 \mathrm{gm}$ or none of proteins per day. In our study half of proteinuria patients had RF showing statistical significance have corrected with western studies, $(\mathrm{P}=0.021)$.

In our study, $53.5 \%$ of patients suffered acute RF. Bourgoignie JJ has reported ARF in upto $55 \%$ of AIDS patients in a study. Joffrey B, Kopp MD, National Institute of Health, Bethesda, has published in Current Infections Disease Reports 2002, that approximately $14 \%$ of black patients and $6 \%$ of white patients died with HIV-1 infection in 1999 in the US has renal disease. Overall, $10 \%$ of patients dying with HIV infection had RF. Our study correlates with western studies showed with statistical significance. The high incidence may be due to late arrival, negligence by relatives and society, poverty and poor intake of fluids and diets, and native drug ingestion.

Renomegaly was noted in $43.3 \%$ of our patient (13 cases). Though we did not do renal biopsy in our patients, we indirectly infer that HIVAN is noted in half of the patients. Other factors like hypovolaemia and sepsis may be present in patients who do not have renomegaly. Di Fiori et al, showed that 30 kidneys (20\%) were enlarged out of 152 cases examined.(17) About half of the patients with RF have renomegaly. Causes of renomegaly had been already discussed earlier.(3) Our observation is shown with statistical significance $(\mathrm{P}=0.04899)$ in our study. Proteinuria $>1$ gm/day noted in 6 patients only. But renomegaly was noted in 13 patients. Renal biopsy must have thrown more light about the severity of glomerular and tubular lesions characteristics of HIVAN.

In our study, $46.87 \%$ of patients (14 cases) did not have RF. But 5 patients presented with renomegaly without RF. Characteristically, all the patients presented with proteinuria in our study had mild-to-severe renal insufficiency as evidenced by reduced creatinine clearance. In our study, 15 out of 30 patients had RF with mean creatinine clearance of $27.65 \mathrm{~mL} / \mathrm{min}$ showing statistical significance. So from our study, it may be assumed that HIV patients presented renal insufficiency, significant proteinuria and renomegaly may have HIVAN.

In our study, hyponatraemia was noted in $53.3 \%$ of patients which correlates with the reference. Tang $\mathrm{W}$ et al, reported that hyponatraemia in $30 \%-60 \%$ of hospitalised symptomatic HIV/ AIDS patients.(13) In our study, all the RF patients had hyponatraemia. This observation is shown with statistical significance in our study. $(\mathrm{P}=0.0001)$ Most of our patients presented with hyponatraemia due to GI losses and salt loosing state.

Hyperkalaemia was noted in $50 \%$ of patients $(15 / 30)$ carrying statistical significance, $(\mathrm{P}=0.0004)$. This correlates with Caramelo $\mathrm{C}$ et al, reporting hyperkalaemia in $30 \%$ of patients. Both hyperkalaemia and hyponatraemia may also be a manifestation of mineralocorticoid deficiency due to adrenal insufficiency.(26) Development of hyperkalaemia by a mechanism unrelated to renal excretion has also been reported in HIV patients.(27)

\section{CONCLUSION}

1. Prevalence of renal failure among HIV patients admitted to tertiary care hospital is $8.3 \%$.

2. About half the patients presented with renal failure $(53.3 \%)$.

3. Nephromegaly was noted in $43.3 \%$.

4. Most of our patients presented with mild proteinuria $(80 \%)$.

5. $\quad 76.6 \%$ presented with pulmonary tuberculosis.

6. Renal biopsy must have thrown more light about the severity of glomerular and tubular lesions characteristics of HIVAN. But due to the severity of the illness, it was not done.

\section{REFERENCES}

[1] Casanova S, Mazzucco G, di Belgiojoso BG, et al. Pattern of glomerular involvement in human immunodeficiency virus-infected patients: an Italian study. Am J Kidney Dis 1995;26(3):446-53.

[2] Kimmel PL, Umana WO, Bosch JP. Abnormal urinary protein excretion in HIV-infected patients. Clin Nephrol 1993;39(1):17-21.

[3] Tang WW, Kaptein EM, Feinstein EI, et al. Hyponatremia in hospitalized patients with the acquired immunodeficiency syndrome and the AIDSrelated complex. Am J Med 1993;94(2):169-74.

[4] Bourgognie JJ. Renal complications of HIV type-1. Kidney GF 1990;37(6):1571-84.

[5] Glassock RJ, Cohen AH, Danovitch G, et al. HIV infection and the kidney. Ann intern Med 1990;112(1):35-49.

[6] Shusterman N, Strom B, Murray T, et al. Risk factors and outcome of hospital acquired acute renal failure. Clinical epidemiology study. Am J Med 1987;83(1):6571.

[7] Bauer FA, Wear DJ, Angritt P, et al. Mycoplasma fermentans (incognitus strain) infection in the kidneys of patients with acquired immunodeficiency syndrome and associated nephropathy: a light microscopic, immunohistochemical, and ultrastructural study. Hum Pathol 1991;22(1):63-9. 
[8] Moyle GJ, Datta D, Mandalia S, et al. Hyperlactatemia and lactic acidosis during antiretroviral therapy: relevance reproducibility and possible risk factors. AIDS 2002;16(10):1341-9.

[9] Simon DI, Brosius FC, Rothstein DM. Sulfadiazine crystalluria revisited. The treatment of toxoplasma encephalitis in patients with acquired immunodeficiency syndrome. Arch Intern Med 1990;150(11):2379-84.

[10] Humphreys MH. Human immunodeficiency virusassociated glomerulosclerosis. Kidney Int 1995;48(2):311-20.

[11] Michel C, Dosquet P, Ronco P, et al. Nephropathy associated infection by HIV: a report on 11 cases including 6 treated with zidovudine. Nephron 1992;62:434-40.

[12] Smith MC, Pawar R, Carey JT, et al. Effect of corticosteroid therapy on HIV associated nephropathy. Am J Med 1994;97(2):145-51.

[13] Marras D, Bruggeman LA, Gao F, et al. Replication and compartmentalization of HIV-1 in kidney epithelium of patients with HIV-associated nephropathy. Nat Med 2002;8(5):522-6.

[14] Rao TK. Clinical features of HIV associated nephropathy. Kidney Int 1991;40(Suppl 35):S13-8.

[15] Bourgoignie JJ, Meneses R, Ortiz C, et al. The clinical spectrum of renal disease associated with with human immunodeficiency virus. Am J Kidney Dis 1988;12(2):131-7.

[16] Ray P, Bruggeman L, Klotman P, et al. BTGF and its low affinity receptors in the pathogenesis of HIV-AN in transgeni mice. Kidney Int 1994;46(3):759-72.
[17] Carbone L, D'Agati V, Cheng JT, et al. Couse and prognosis of HIV-AN. Am J Med 1989;87:389-95.

[18] Szczech LA, Gange SJ, van der Horst C, et al. Predictors of proteinuria and renal failure among women with HIV infection. Kidney Inf 2002;61(1):195-202.

[19] Winston JA, Bruggeman LA, Ross MD, et al. Nephropathy and establishment of a renal reservoir of HIV type-1 during primary infection. N Eng J Med 2001;344(26):1979-84.

[20] Alvaro F, Lundin P, Chirgwin K, et al. Proteinuria in HIV infected patients. J Am Soc Nephrol 1990;1:306.

[21] Eustace JA, Nuermberger E, Choi M, et al. Cohort study of the treatment of severe HIV-AN with corticosteroids. kidney Int 2000;58(3):1253-60.

[22] Rall C, Dienstag J. Epidemiology of HCV infection. Semin Gastrointest Dis 1995;6:3-12.

[23] Winston JA, Klotman PE. Are we missing an epidemic of HIV-AN? J Am Soc Nephrol 1996;7(1):1-7.

[24] Farzadegan H, Ford D, Malan M, et al. HIV-1 survival kinetics in peritoneal dialysis effluent. Kidney Int 1996;50(5):1659-62.

[25] Schoenfeld P, Feduska NJ. Acquired immunodeficiency syndrome and renal disease: report of the national kidney foundation-national institutes of health task force on AIDS and kidney disease. AM J Kidney Dis 1990;16(1):14-25.

[26] Caranels C. Hyperkalemia in patients infected with HIV virus: involvement of a systematic mechanism. Kidney Gt 1999;56(1):198-205.

[27] Pardo V, Aldana M, Colton RM, et al. Glomerular lesions in the acquired immunodeficiency syndrome. Ann Int Med 1984:101(4):429-34. 